\title{
Article \\ Soil Quality as a Key Factor in Producing Vegetables for Home Consumption-A Case Study of Urban Allotments in Gorzów Wielkopolski (Poland)
}

\author{
Maciej Bosiacki ${ }^{1}$, Leszek Bednorz ${ }^{2, *}$, Konstancja Fedeńczak ${ }^{3}$, Tomasz Górecki ${ }^{4}\left(\mathbb{D}\right.$, Andrzej Mizgajski ${ }^{3}$, \\ Lidia Poniży ${ }^{3}$ and Tomasz Spiżewski ${ }^{5}$
}

1 Department of Plant Nutrition, Faculty of Agronomy, Horticulture and Bioengineering, Poznań University of Life Sciences, Zgorzelecka 4, 60-198 Poznań, Poland; maciej.bosiacki@up.poznan.pl

2 Department of Botany, Faculty of Agronomy, Horticulture and Bioengineering, Poznań University of Life Sciences, Wojska Polskiego 71c, 60-625 Poznań, Poland

3 Department of Integrated Geography, Faculty of Human Geography and Planning, Adam Mickiewicz University, Bogumiła Krygowskiego 10, 61-680 Poznań, Poland; konstancja.fedenczak@amu.edu.pl (K.F.); andrzej.mizgajski@amu.edu.pl (A.M.); lidia.ponizy@amu.edu.pl (L.P.)

4 Department of Mathematical Statistics and Data Analysis, Faculty of Mathematics and Computer Science, Adam Mickiewicz University, Poznańskiego 4, 61-614 Poznań, Poland; tomasz.gorecki@amu.edu.pl

5 Department of Vegetable Crops, Faculty of Agronomy, Horticulture and Bioengineering, Poznań University of Life Sciences, Jana Henryka Dąbrowskiego 159, 60-995 Poznań, Poland; tomasz.spizewski@up.poznan.pl

* Correspondence: leszek.bednorz@up.poznan.pl

\section{check for} updates

Citation: Bosiacki, M.; Bednorz, L.; Fedeńczak, K.; Górecki, T.; Mizgajski, A.; Poniży, L.; Spiżewski, T. Soil Quality as a Key Factor in Producing Vegetables for Home

Consumption-A Case Study of Urban Allotments in Gorzów Wielkopolski (Poland). Agronomy 2021, 11, 1836. https://doi.org/ 10.3390/agronomy11091836

Academic Editor: Jinman Wang

Received: 28 July 2021

Accepted: 8 September 2021

Published: 13 September 2021

Publisher's Note: MDPI stays neutral with regard to jurisdictional claims in published maps and institutional affiliations.

Copyright: (c) 2021 by the authors. Licensee MDPI, Basel, Switzerland. This article is an open access article distributed under the terms and conditions of the Creative Commons Attribution (CC BY) license (https:// creativecommons.org/licenses/by/ $4.0 /)$.

\begin{abstract}
The aim of the study was to analyse the quality of soil in urban allotment gardens in the context of the production of home-grown vegetables. The study was conducted on six allotment gardens (31 individual plots) in Gorzów Wielkopolski, a medium-sized Polish city with an average level of industrialisation. The following soil characteristics were analysed: $\mathrm{pH}$, electric conductivity, organic matter, organic carbon, humus, total nitrogen, $\mathrm{C}: \mathrm{N}$ ratio, $\mathrm{NH}_{4}{ }^{+}-\mathrm{N}, \mathrm{NO}_{3}-\mathrm{N}^{-}, \mathrm{P}, \mathrm{K}, \mathrm{Ca}, \mathrm{Mg}$, $\mathrm{SO}_{4}{ }^{-}-\mathrm{S}, \mathrm{Cl}, \mathrm{Na}, \mathrm{Fe}, \mathrm{Cu}, \mathrm{Zn}, \mathrm{Mn}, \mathrm{Ni}, \mathrm{Cr}, \mathrm{Cd}, \mathrm{Pb}$. The analyses showed that the soils were abundant in necessary nutrients for vegetable growing. They had high content of calcium, magnesium, and phosphorus. However, the soil $\mathrm{pH}$ in areas of vegetable cropping was too high. The content of toxic heavy metals—cadmium (0.22-0.59 $\mathrm{mg} \cdot \mathrm{kg}^{-1} \mathrm{~d} . \mathrm{m}$.) and lead (3.46-16.89 $\mathrm{mg} \cdot \mathrm{kg}^{-1} \mathrm{~d} . \mathrm{m}$.) —was within the acceptable limits. Nevertheless, the chemical analysis of carrots used as test vegetables showed that the permissible limits of cadmium and lead content in their roots were exceeded. The excessive uptake of these toxic metals can be reduced by lowering the soil $\mathrm{pH}$ and applying organic carbon to the soil.
\end{abstract}

Keywords: urban agriculture; allotment gardens; food security; urban soils; heavy metals; Poland

\section{Introduction}

Cities are an important element in the food system because, on the one hand, they generate the demand for food for urban residents and, on the other hand, they are also the places where food is produced in urban and peri-urban areas. At present, more than half of the world population lives in cities. Crop cultivation in cities has several major advantages such as the reduction of food miles and connecting people with nature [1]. Allotment gardens (AGs) are an important component of urban agriculture. They have been present in many European countries, including Poland, since the 19th century. Food provision has been the most important function of AGs for many years. Nowadays, allotment gardens are increasingly used for leisure and recreation in Poland, but the cultivation of crops is still important for a substantial group of AGs users [2]. According to the Statistical Yearbook of Agriculture [3], currently, there are 4677 allotment gardens in Poland. They occupy an area of 40,863.0 ha, including 917,445 plots with an area of 32,181.2 ha (2016). 
Allotment gardeners, who use publicly owned urban space, are the largest group of city land managers [4].

Food safety is a key issue in the production of home-grown vegetables in cities [5-10]. The question arises as to whether urban soil is a good substrate to produce vegetables for home consumption due to the risk of its contamination with metals [6,10-12]. Vegetables grown on urban soils with a high concentration of heavy metals (especially toxic ones) may accumulate these toxins in edible parts, and when consumed, they are incorporated into the food chain.

The following aims of the study were formulated: (1) assessment of the abundance of nutrients in the soil necessary for vegetable growing and assessment of the contamination of soil in allotment gardens with heavy metals; (2) assessment of the quality of carrots (Daucus carota subsp. sativus) grown in the allotment gardens, with a special focus on the content of heavy metals. An additional aim of the study was to formulate recommendations concerning the fertilisation of soil in allotment gardens.

In order to achieve the aims of the study, soil and carrots from the allotment gardens in Gorzów Wielkopolski, a medium-sized Polish city with an average level of industrialisation, were analysed. The research was the Polish part of the international project 'FEW-Meter-an Integrative Model to Measure and Improve Urban Agriculture towards Circular Urban Metabolism', implemented between 2018 and 2021. In addition to Poland, four other countries are participating in the project, i.e., Germany, France, the United Kingdom, and the United States. They are conducting extensive research on the food-energy-water nexus in urban agriculture in selected cities (find out more about the project online: www.fewmeter.org accessed on 25 August 2021).

\section{Materials and Methods}

\subsection{Study Area-City of Gorzów Wielkopolski}

Gorzów Wielkopolski is a city in northwestern Poland. It occupies an area of nearly $86 \mathrm{~km}^{2}$ and has a population of nearly 124,000. According to the physico-geographical regionalisation of Poland [13], Gorzów Wielkopolski lies within two morphogenetically different units: Gorzów Plain and Gorzów Basin. The Gorzów Plain mesoregion, belonging to the Southern Pomerania Lakeland macroregion, covers an area located from the latitudinally running Warta River to the north. It is an upland area with a plain and undulating terrain made up of clay, loamy sand, and sandy and gravel deposits of Pleistocene North Polish Glaciations. From the south, this upland area is limited by the edge zone, which is much more diversified in terms of relief. To the south of this zone, there is a flat, sparsely diversified Gorzów Basin belonging to Torun-Eberswalde Ice Marginal Valley macroregion. The Gorzów Basin is built of Holocene river deposits such as silt and fluvisols, covering the right and the left bank terraces of the Warta River [14,15]. The development of the urban area is affected by natural conditions in the city. The areas located on the upland are more developed and more densely built-up than the areas located south of the Warta. The built-up and urbanised land occupies $31 \mathrm{~km}^{2}$, which is slightly more than $36 \%$ of the city area. It is slightly less than the average percentage of built-up and urbanised land in the total area of Polish cities with more than 100,000 inhabitants, which amounts to about $40 \%$. There is a considerable share of bioactive areas in Gorzów Wielkopolski. These areas include: agricultural land (more than $50 \%$ of the city area), forest lands (slightly more than $8 \%$ of the city area), designated green space ( $4.6 \%$ of the city area), and surface waters (less than $2 \%$ of the city area). According to the Central Statistical Office, agricultural land also includes allotment gardens, whose area is nearly 340 ha, i.e., about $4 \%$ of the total area of the city. In Gorzów Wielkopolski, there are 36 allotment gardens (AGs) with about 8000 individual allotment plots. If we assume that each allotment plot used by a family of three, this means that the allotment gardens are used by about 24,000 people, i.e., almost a fifth of the city population. Apart from the recreational function of allotment gardens, they also provide food to their users. In Gorzów Wielkopolski, on average, $23.5 \%$ of the allotment garden area is used for the production of fruit and vegetables, and the rest is 
occupied by lawn, flower beds, ornamental trees, and shrubs as well as a small house, terrace, and pavement [16].

Weather conditions are important for horticultural crops. The analyses of soil and carrots were made in 2019, which was the hottest year in Poland in the last 50 years. The average annual air temperature in Gorzów Wielkopolski was $11.0^{\circ} \mathrm{C}$. It was higher than the average annual air temperature in Poland, i.e., $10.2^{\circ} \mathrm{C}$. In 2019 , the total annual rainfall was $555.5 \mathrm{~mm}$, and it was lower than the average total annual rainfall in Poland, i.e., $573.3 \mathrm{~mm}[17]$.

\subsection{AGs Selection}

The quality of soil and plant material was tested on 31 allotment plots participating in the FEW-meter project. The gardens participating in the project belong to 6 of $36 \mathrm{AGs}$ located in Gorzów Wielkopolski (Figure 1).

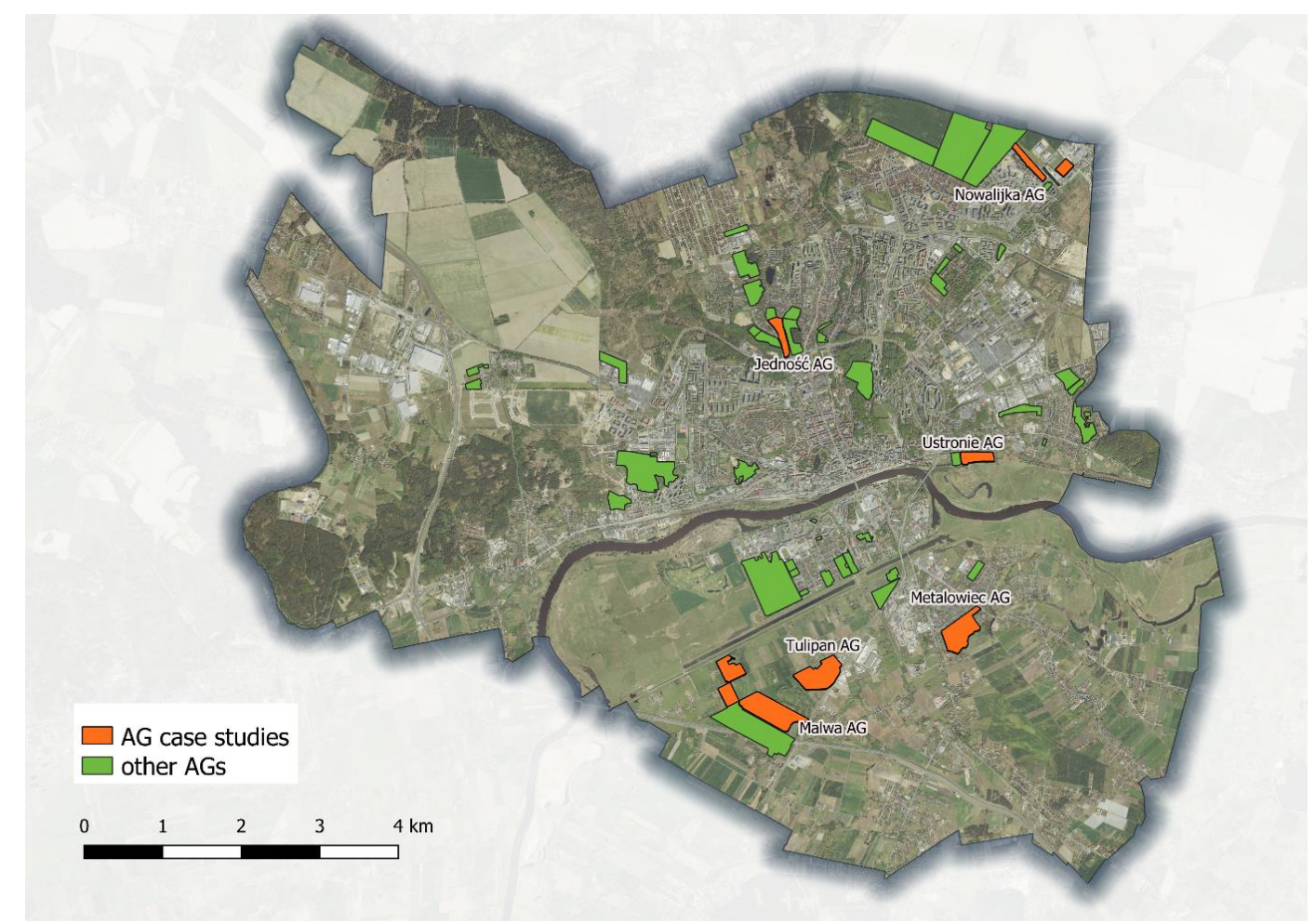

Figure 1. The location of the allotment gardens in Gorzów Wielkopolski where the quality of soil and plant material was tested.

According to historical cartographic studies (Messtischblatt topographic maps 1:25,000 made in 1936), the Jedność AG, located closest to the city centre, was built on the site of a former brickyard; the Ustronie AG was built on the meadows along the Warta River; the Nowalijka, the Malwa, the Metalowiec, and the Tulipan AGs were established on agricultural lands and meadows located on the outskirts of the city. All the AGs have been used for many years. The Nowalijka AG, which is the youngest, was established 37 years ago.

In each of the AGs, 3-8 allotment plots were involved in the project. The areas of the plots ranged from $277 \mathrm{~m}^{2}$ to $505 \mathrm{~m}^{2}$ (average area $365 \mathrm{~m}^{2}$ ). Fruit and vegetables were grown only in part of this area. There were very large differences in the area of fruit and vegetable cropping in the allotment plots-its share in the total area of the plot ranged from slightly more than $6 \%$ to almost $77 \%$ (Table 1 ). The most common vegetables grown on the allotments were: tomatoes, cucumbers, carrots, and beets. 
Table 1. AGs characteristics.

\begin{tabular}{|c|c|c|c|c|c|c|}
\hline Name of AG & $\begin{array}{c}\text { Year of } \\
\text { Establishment }\end{array}$ & $\begin{array}{c}\text { AG Area } \\
\text { [ha] }\end{array}$ & $\begin{array}{l}\text { No. of } \\
\text { Plots }\end{array}$ & Water Supply & $\begin{array}{l}\text { Average Area of } \\
\text { Plots }\left(\mathrm{m}^{2}\right)\end{array}$ & $\begin{array}{c}\text { Average Cultivation } \\
\text { Area }\left(\mathrm{m}^{2}\right)\end{array}$ \\
\hline Jedność & 1971 & 4.69 & 120 & City water supply system & 401.6 & 60.0 \\
\hline Malwa & 1977 & 32.35 & 718 & Rainwater/Individual wells & 312.5 & 101.8 \\
\hline Metalowiec & 1959 & 14.66 & 364 & Drilled well in AG & 345.8 & 128.6 \\
\hline Nowalijka & 1984 & 6.73 & 142 & City water supply system & 429.0 & 136.0 \\
\hline Tulipan & 1982 & 15.31 & 294 & Drilled well in AG & 392.3 & 114.5 \\
\hline Ustronie & 1975 & 5.12 & 165 & Drilled well in AG & 297.8 & 25.8 \\
\hline
\end{tabular}

AG-allotment garden.

\subsection{Soil and Plant Material Sampling}

Soil samples for chemical analyses were collected on 15 April 2019. Ten individual samples were collected from each of the 31 allotment plots, and they were used as one mixed sample. The samples were collected with a soil probe from a depth of $0.0-20.0 \mathrm{~cm}$ at the sites where vegetables were grown. In total, 310 individual samples were collected, amounting to 31 mixed samples.

Samples of plant material consisting of carrot roots and shoots were collected from 24 allotment plots. The number of allotment plots in individual AGs from which soil and plant material samples were collected is shown in Table 2.

Table 2. The number of allotment plots from which soil and plant material samples were collected.

\begin{tabular}{ccc}
\hline Name of AG & No. of Plots-Soil & No. of Plots-Plants \\
\hline Jedność & 3 & 2 \\
Malwa & 5 & 2 \\
Metalowiec & 5 & 5 \\
Nowalijka & 5 & 4 \\
Tulipan & 8 & 7 \\
Ustronie & 5 & 4 \\
\hline
\end{tabular}

\subsection{Soil Analysis}

After sampling, the soil material was dried, sieved, cleaned of mechanical impurities, and transferred to a laboratory for chemical analyses, which were performed in two replications.

The soil $\mathrm{pH}_{\mathrm{H} 2 \mathrm{O}}$ was measured using the potentiometric method (soil:water volume ratio $1: 2 \mathrm{v} / \mathrm{v})$. Electric conductivity EC $\left(\mathrm{ms} \cdot \mathrm{cm}^{-1}\right)$ was measured by means of conductometry (soil:water volume ratio 1:2 v/v) [18]. The content of available macronutrients and sodium in the soil was measured using the 'universal' method in a $\mathrm{CH}_{3} \mathrm{COOH}$ solution concentrated at $0.03 \mathrm{~mol} \cdot \mathrm{dm}^{-1}$ [19]. The following techniques were used to measure the content of macronutrients and sodium: $\mathrm{NH}_{4}{ }^{+}-\mathrm{N}$ and $\mathrm{NO}_{3}{ }^{-}-\mathrm{N}$-distillation, P-the molybdenumvanadium colorimetric method, $\mathrm{K}, \mathrm{Ca}$ and $\mathrm{Na}$-flame photometry, $\mathrm{Mg}$-atomic absorption spectrometry, $\mathrm{SO}_{4}{ }^{-}$-S-colorimetric method [19].

The total $\mathrm{N}$ content was determined with the Kjeldahl method; the organic carbon and the humus content were determined with the Tyurin method [20]. The percentage of organic matter in the soils was determined by heating the substrate directly at high temperature $\left(440^{\circ} \mathrm{C}\right)$ in the presence of oxygen [20].

Available microelements $(\mathrm{Fe}, \mathrm{Mn}, \mathrm{Zn}, \mathrm{Cu}, \mathrm{Ni})$ and toxic heavy metals $(\mathrm{Cd}, \mathrm{Cr}, \mathrm{Pb})$ were extracted from dry soil with a modified Lindsay solution containing $5 \mathrm{~g}$ EDTA (ethylenediaminetetraacetic acid), $9 \mathrm{~cm}^{3}$ of a $25 \% \mathrm{NH}_{4} \mathrm{OH}$ solution, $4 \mathrm{~g}$ of citric acid, and $2 \mathrm{~g} \mathrm{Ca}\left(\mathrm{CH}_{3} \mathrm{COO}\right)_{2} 2 \mathrm{H}_{2} \mathrm{O}$ in $1 \mathrm{dm}^{3}$ [21]. The content of micronutrients and heavy metals was determined by means of flame atomic absorption spectroscopy (FAAS) with an AAS 5 Zeiss apparatus. 


\subsection{Chemical Analysis of Plant Material}

After harvesting the carrot, roots and shoots were dried in an exhaust dryer at a temperature of $105^{\circ} \mathrm{C}$ for $48 \mathrm{~h}$. The plant material was wet-mineralised in a mixture of ultrapure $\mathrm{HNO}_{3}$ and pure $\mathrm{HClO}_{4}(3: 1 v / v)$ [22].

The content of cadmium, chrome, copper, lead, nickel, manganese, and zinc in the plant material was measured by means of flame atomic absorption spectroscopy (FAAS) with an AAS-5 spectrophotometer (Carl Zeiss, Jena, Germany). The analyses were performed in two replications.

The carrot root tubers were analysed for the content of: extract total soluble solids $\left({ }^{\circ} \mathrm{Bx}\right)$ with a DR-103L electronic refractometer, dry weight at $105{ }^{\circ} \mathrm{C}$ according to the Polish standard PN-90A-75101/03, soluble sugars with the anthrone method [23], and betacarotene by means of spectrophotometry (Specord 50 Plus, Analytik Jena, Jena, Germany) according to the Polish standard PN-90A-75101/12. The content of nitrate in the carrot roots was measured spectrophotometrically (Kjeltec System 1002 Distilling Unit, FOSS Tecator, Hgans, Sweden) according to the Polish standard [24]. In total, 21 samples (no replications) were analysed using these methods.

\subsection{Statistical Analyses}

The results were analysed statistically to determine minimum, maximum, average, standard deviation (SD), and coefficients of variation (CV) for individual chemical parameters of the soil and the plant samples from individual plots.

Principal component analysis (PCA) was applied to examine differences between the allotment plots in the soil characteristics and the concentration of elements in the carrot roots.

Hierarchical cluster analysis was applied to confirm the PCA results [25]. It enabled a more specific look at the similarities and the differences between the allotment plots and helped to identify groups of plots with similar information searches. The clustering was based on the Ward method, which was the most suitable.

One-way analysis of variance (ANOVA) was used to compare the effect of soil characteristics and the content of elements in the carrots on differences between the AGs for each variable separately. Differences between the means were determined at a significance level $\alpha=0.05$ (marked with an asterisk in the tables). Furthermore, we applied Fisher's least significant difference method [26] with Holm correction for multiple testing to detect homogenous groups of AGs (marked with small letters in the tables).

The Pearson correlation coefficient was used to measure the strength of the relationship between the variables under analysis. We also studied the relationship between the soil $\mathrm{pH}$ and the soil organic carbon content as well as the heavy metals $(\mathrm{Pb}, \mathrm{Cd})$ content in soil and carrot roots using ANOVA.

The R software (The R Foundation, Vienna, Austria) [27] was used for all statistical analyses.

\section{Results}

The study showed that the soil pH in the allotment gardens in Gorzów Wielkopolski was relatively homogeneous and exhibited low variability $(\mathrm{CV}=4.75 \%)$ (Tables 3 and 4 ). The $\mathrm{pH}_{\mathrm{H} 2 \mathrm{O}}$ value in the topsoil ranged from 6.56 to 8.22 . The mean value of soil $\mathrm{pH}_{\mathrm{H} 2 \mathrm{O}}$ in the allotment plots in Gorzów Wielkopolski was 7.44. There were no acidic soils. Most of the soils were alkaline $\left(\mathrm{pH}_{\mathrm{H} 2 \mathrm{O}}>7.5\right) 58.1 \%$; the share of neutral soils $\left(\mathrm{pH}_{\mathrm{H} 2 \mathrm{O}} 6.8-7.4\right)$ was $35.5 \%$, whereas the share of slightly acidic soils $\left(\mathrm{pH}_{\mathrm{H} 2 \mathrm{O}} 6.1-6.7\right)$ amounted to $6.4 \%$. 
Table 3. Soil reaction, EC, content of organic matter, organic carbon, humus, total nitrogen, and the C:N ratio of 31 allotment plots in Gorzów Wielkopolski.

\begin{tabular}{|c|c|c|c|c|c|c|c|}
\hline \multirow{2}{*}{ Statistics } & \multirow{2}{*}{$\mathrm{pH}_{\mathrm{H} 2 \mathrm{O}}$} & \multirow{2}{*}{$\begin{array}{c}\mathrm{EC} \\
\left(\mathrm{mS} \mathrm{cm}^{-1}\right)\end{array}$} & Organic Matter & C Org & Humus & N Total & \multirow{2}{*}{ C:N } \\
\hline & & & \multicolumn{4}{|c|}{$\%$} & \\
\hline $\min$. & 6.56 & 0.13 & 3.18 & 0.51 & 0.88 & 0.07 & 6.38 \\
\hline $\max$ & 8.22 & 0.87 & 57.17 & 4.26 & 7.34 & 0.16 & 26.63 \\
\hline mean & 7.44 & 0.34 & 10.46 & 1.13 & 1.94 & 0.10 & 11.79 \\
\hline SD & 0.35 & 0.16 & 9.36 & 0.59 & 1.02 & 0.03 & 4.06 \\
\hline $\mathrm{CV}(\%)$ & 4.75 & 47.29 & 89.54 & 52.67 & 52.65 & 28.50 & 34.40 \\
\hline
\end{tabular}

Table 4. Soil reaction, EC, content of organic matter, organic carbon, humus, total nitrogen, and the C:N ratio of six allotment gardens in Gorzów Wielkopolski.

\begin{tabular}{|c|c|c|c|c|c|c|c|}
\hline \multirow{2}{*}{ AGs } & \multirow{2}{*}{$\mathrm{pH}_{\mathrm{H} 2 \mathrm{O}}$} & \multirow{2}{*}{$\begin{array}{c}\mathrm{EC} \\
\left(\mathrm{mS} \mathrm{cm}^{-1}\right)\end{array}$} & Organic Matter & C Org & Humus & N Total & \multirow{2}{*}{$\mathrm{C}: \mathrm{N}$} \\
\hline & & & \multicolumn{4}{|c|}{$\%$} & \\
\hline Jedność & 7.57 & 0.29 & 17.81 & 1.04 & 1.80 & 0.08 & 13.75 \\
\hline Malwa & 7.37 & 0.43 & 8.14 & 1.16 & 1.99 & 0.11 & 11.63 \\
\hline Metalowiec & 7.15 & 0.40 & 17.07 & 1.67 & 2.88 & 0.12 & 13.88 \\
\hline Nowalijka & 7.71 & 0.31 & 11.20 & 0.88 & 1.52 & 0.09 & 10.53 \\
\hline Tulipan & 7.29 & 0.28 & 6.60 & 0.99 & 1.70 & 0.09 & 11.14 \\
\hline Ustronie & 7.67 & 0.32 & 11.31 & 1.07 & 1.84 & 0.10 & 11.72 \\
\hline$p$-value & 0.055 & 0.640 & 0.345 & 0.385 & 0.385 & 0.366 & 0.794 \\
\hline
\end{tabular}

The soils in the allotment gardens in Gorzów Wielkopolski were composed of slightly loamy sands, except for the sample collected from the Metalowiec AG No. 2, which was an organic substrate with an organic matter content of $57.17 \%$. In the remaining soils, which were slightly loamy sands, the content of organic matter ranged from $3.18 \%$ to $20.09 \%$. The soils in the allotment gardens in Gorzów Wielkopolski were characterised by very strong variability in the organic matter content (Table 3).

The humus content in the topsoil ranged from $0.88 \%$ to $7.34 \%$, whereas the organic carbon content ranged from $0.51 \%$ to $4.26 \%$. These soils were characterised by high variability. The C:N ratio ranged from 6.38 to 26.63 (average ratio 11.79) and exhibited moderate variability (Table 3). The $\mathrm{C}: \mathrm{N}$ ratio has significant influence on the decomposition of soil organic matter. The C:N ratio in mineral soils is usually (10-15):1. This carbon to nitrogen ratio is considered normal. Soil organic matter is decomposed by microorganisms which need nitrogen, carbon, and other nutrients. The total nitrogen content in the arable layer of most mineral soils ranges from $0.02 \%$ to $0.6 \%$. In our study, the total nitrogen content in the topsoil ranged from $0.07 \%$ to $0.16 \%$ (average content $0.10 \%$ ) and was moderately variable. The soils in the allotment gardens in Gorzów Wielkopolski had low total nitrogen content.

The analysis of the content of macronutrients, chloride, and sodium (Table 5) in the topsoil of the allotment plots in Gorzów Wielkopolski revealed a significant average content of calcium (2553.1 mg $\cdot \mathrm{kg}^{-1}$ of soil), magnesium ( $266.3 \mathrm{mg} \cdot \mathrm{kg}^{-1}$ of soil), and phosphorus (179.4 mg $\mathrm{kg}^{-1}$ of soil) but a low content of mineral nitrogen. There was high variability in the content of $\mathrm{NH}_{4}{ }^{+}-\mathrm{N}, \mathrm{P}, \mathrm{K}, \mathrm{SO}_{4}{ }^{-}-\mathrm{S}, \mathrm{Cl}$, and $\mathrm{Na}$ and very high variability in the content of $\mathrm{NO}_{3}{ }^{-}-\mathrm{N}$. The analysis of variance showed that the allotment gardens under study were significantly differentiated by the content of phosphorus, chloride, and sodium (Table 6). The soils of the allotment gardens were characterised by moderate variability in $\mathrm{Ca}$ and $\mathrm{Mg}$ content. The analysis of the abundance of nutrients in the soils for the cultivation of vegetables, including carrots, revealed high content of calcium, magnesium, and phosphorus. According to Komosa et al. [28], the recommended ranges for carrots grown in a field are: $\mathrm{NH}_{4}{ }^{-} \mathrm{N}+\mathrm{NO}_{3}{ }^{-}-\mathrm{N}$ 50-130, P 40-60, $\mathrm{K}$ 150-200, Ca 250-400, Mg $60-120, \mathrm{SO}_{4}{ }^{-} \mathrm{S} 20-40, \mathrm{Na}<50$ and $\mathrm{Cl}<50$. The high content of calcium and magnesium 
influenced the soil $\mathrm{pH}$ (Tables 3 and 4). The optimal $\mathrm{pH}$ for growing carrots in a field is $6.0-6.5 \mathrm{pH}_{\mathrm{H} 2 \mathrm{O}}$ [28].

Table 5. The content of macronutrients, chloride, and sodium in soils of 31 allotment plots in Gorzów Wielkopolski.

\begin{tabular}{|c|c|c|c|c|c|c|c|c|c|}
\hline \multirow{2}{*}{ Statistics } & \multicolumn{9}{|c|}{ Content $\mathrm{mg} \cdot \mathrm{kg}^{-1} \mathrm{~d} . \mathrm{m}}$. \\
\hline & $\mathrm{NH}_{4}{ }^{+}-\mathrm{N}$ & $\mathrm{NO}_{3}{ }^{-}-\mathrm{N}$ & $\mathbf{P}$ & K & $\mathrm{Ca}$ & Mg & $\mathrm{SO}_{4}^{-}-\mathrm{S}$ & $\mathrm{Cl}$ & $\mathrm{Na}$ \\
\hline $\min$. & 0.1 & 0.1 & 26.4 & 12.0 & 504.4 & 52.3 & 9.3 & 8.1 & 10.2 \\
\hline $\max$ & 52.5 & 112.0 & 507.3 & 606.9 & 4531.3 & 492.5 & 231.7 & 45.1 & 61.0 \\
\hline mean & 13.8 & 22.8 & 179.4 & 190.2 & 2553.1 & 266.3 & 48.5 & 18.0 & 28.5 \\
\hline $\mathrm{SD}$ & 12.2 & 25.4 & 104.0 & 129.3 & 1146.4 & 114.7 & 46.4 & 8.6 & 14.5 \\
\hline CV (\%) & 88.5 & 111.3 & 58.0 & 67.9 & 44.9 & 43.1 & 95.8 & 47.6 & 51.0 \\
\hline
\end{tabular}

Table 6. The content of macronutrients, chloride, and sodium in soils of six allotment gardens in Gorzów Wielkopolski.

\begin{tabular}{|c|c|c|c|c|c|c|c|c|c|}
\hline \multirow{2}{*}{ AGs } & \multicolumn{9}{|c|}{ Content $\mathrm{mg} \cdot \mathrm{kg}^{-1} \mathrm{~d} . \mathrm{m}}$. \\
\hline & $\mathrm{NH}_{4}{ }^{+}-\mathrm{N}$ & $\mathrm{NO}_{3}{ }^{-}-\mathrm{N}$ & $\mathbf{P}$ & K & $\mathrm{Ca}$ & $\mathrm{Mg}$ & $\mathrm{SO}_{4}{ }^{-}-\mathrm{S}$ & $\mathrm{Cl}$ & $\mathrm{Na}$ \\
\hline Jedność & 7.07 & 38.50 & $123.75^{b, * *}$ & 178.83 & 3378.63 & 295.93 & 26.50 & $12.08^{a b}$ & $12.13^{b}$ \\
\hline Malwa & 20.30 & 23.10 & $150.22^{a b}$ & 300.14 & 2535.58 & 331.82 & 59.05 & $16.78^{a b}$ & $21.50^{b}$ \\
\hline Metalowiec & 15.40 & 35.72 & $159.83^{a b}$ & 226.54 & 1884.32 & 246.04 & 43.88 & $21.99 \mathrm{ab}$ & $27.44^{\mathrm{ab}}$ \\
\hline Nowalijka & 7.02 & 7.74 & $325.02^{a}$ & 223.12 & 3136.68 & 207.20 & 66.14 & $11.15^{b}$ & $17.10^{\mathrm{b}}$ \\
\hline Tulipan & 18.81 & 21.89 & $148.74^{b}$ & 149.25 & 1572.25 & 220.80 & 45.70 & $25.51^{a}$ & $43.71^{\mathrm{a}}$ \\
\hline Ustronie & 8.42 & 16.80 & $164.68^{a b}$ & 83.30 & 3730.10 & 334.96 & 42.42 & $13.57^{a b}$ & $33.16^{\mathrm{ab}}$ \\
\hline$p$-value & 0.308 & 0.530 & 0.024 * & 0.128 & 0.385 & 0.298 & 0.902 & 0.011 * & $0.001 *$ \\
\hline
\end{tabular}

* statistically significant $(\alpha=0.05) ;{ }^{* *}$ means followed by the same letters do not differ significantly at $(\alpha=0.05)$.

Soil samples for the analysis of the content of micronutrients and toxic heavy metals $(\mathrm{Cd}, \mathrm{Cr}$, and $\mathrm{Pb})$ were collected from the topsoil, where the plant's root hair system develops. It is responsible for the uptake of both nutrients and heavy metals with water. Some heavy metals (e.g., iron, copper, manganese, zinc, nickel) are necessary elements for the growth and the development of plants, and they are defined as micronutrients. Others are harmful elements, e.g., cadmium, lead, and chromium (toxic metals).

The degree of soil contamination with heavy metals is usually assessed on the basis of the total content of elements. According to Filipek-Mazur and Tabak [29], this assessment should be supplemented with an analysis of the content of heavy metals that are directly accessible to living organisms.

The average copper content in the soil of the allotment plots was $3.86 \mathrm{mg} \cdot \mathrm{kg}^{-1}$. It ranged from 1.20 to $8.14 \mathrm{mg} \cdot \mathrm{kg}^{-1}$ and exhibited moderate variability $(\mathrm{CV}=39.16 \%)$ (Table 7). According to Sady [30], who gives the content of elements in milligrams per litre of soil or substrate, the optimal soil copper content for plant growth should range from 3 to $10 \mathrm{mg} \cdot \mathrm{dm}^{-3}$. The average weight of one litre of soil dry matter in the allotment gardens in Gorzów Wielkopolski was $1085 \mathrm{~g}$.

Table 7. The content of heavy metal in soils of 31 allotment plots in Gorzów Wielkopolski.

\begin{tabular}{ccccccccc}
\hline \multirow{2}{*}{ Statistics } & \multicolumn{8}{c}{ Content $\mathbf{~ m g} \cdot \mathbf{k g} \mathbf{- 1}^{\mathbf{1}} \mathbf{d . m} \cdot$} \\
\cline { 2 - 9 } & $\mathbf{C u}$ & $\mathbf{F e}$ & $\mathbf{N i}$ & $\mathbf{M n}$ & $\mathbf{Z n}$ & $\mathbf{C d}$ & $\mathbf{C r}$ & $\mathbf{P b}$ \\
\hline min. & 1.20 & 47.50 & 0.40 & 12.01 & 4.22 & 0.22 & 0.61 & 3.46 \\
max. & 8.14 & 134.77 & 1.03 & 71.22 & 52.02 & 0.59 & 4.04 & 16.89 \\
mean & 3.86 & 108.73 & 0.64 & 50.32 & 27.98 & 0.37 & 1.05 & 6.85 \\
SD & 1.51 & 22.01 & 0.12 & 20.52 & 11.07 & 0.09 & 0.58 & 2.98 \\
CV $(\%)$ & 39.16 & 20.25 & 18.92 & 40.77 & 39.56 & 24.56 & 54.97 & 43.53 \\
\hline
\end{tabular}


The iron content in the topsoil of the allotment plots in Gorzów Wielkopolski ranged from 47.50 to $134.77 \mathrm{mg} \cdot \mathrm{kg}^{-1}$. The average content of this element was $108.73 \mathrm{mg} \cdot \mathrm{kg}^{-1}$; it was much higher than the content of other micronutrients analysed in our study (Table 7). According to Filipek-Mazur and Tabak [29], the optimal iron content for normal plant growth should be $5-100 \mathrm{mg} \cdot \mathrm{dm}^{-3}$. Most of the tested samples were within the recommended range. However, the average Fe content in Metalowiec, Malwa, and Tulipan AGs (Table 8) was higher than the value recommended by Sady [30]. The highest concentration of soluble forms of this element $\left(134.77 \mathrm{mg} \cdot \mathrm{kg}^{-1}\right)$ was found in the soil of Metalowiec AG No. 2. The soil iron content in the allotment plots in Gorzów Wielkopolski exhibited low variability.

Table 8. The content of heavy metal in soils of six allotment gardens in Gorzów Wielkopolski.

\begin{tabular}{|c|c|c|c|c|c|c|c|c|}
\hline \multirow{2}{*}{ AGs } & \multicolumn{8}{|c|}{ Content $\mathrm{mg} \cdot \mathrm{kg}^{-1} \mathrm{~d} . \mathrm{m}}$. \\
\hline & $\mathrm{Cu}$ & $\mathrm{Fe}$ & $\mathrm{Ni}$ & Mn & Zn & $\mathrm{Cd}$ & $\mathrm{Cr}$ & $\mathrm{Pb}$ \\
\hline Jedność & $5.7^{a, * *}$ & $67.28^{c}$ & 0.59 & $23.10^{\mathrm{b}}$ & $38.89^{a}$ & $0.31^{\mathrm{cd}}$ & 0.93 & 7.88 \\
\hline Malwa & $4.76^{\mathrm{a}}$ & $118.16^{a}$ & 0.60 & $56.41^{a}$ & $31.58^{a b}$ & $0.38^{b c}$ & 1.02 & 5.42 \\
\hline Metalowiec & $3.43^{\mathrm{a}}$ & $125.08^{a}$ & 0.72 & $59.19^{a}$ & $29.83^{a b}$ & $0.33^{c}$ & 0.89 & 6.82 \\
\hline Nowalijka & $2.58^{\mathrm{a}}$ & $95.53^{b}$ & 0.53 & $52.48^{a}$ & $15.93^{b}$ & $0.24^{\mathrm{d}}$ & 1.38 & 4.56 \\
\hline Tulipan & $3.32^{\mathrm{a}}$ & $125.4^{\mathrm{a}}$ & 0.70 & $66.04^{\mathrm{a}}$ & $24.09^{a b}$ & $0.40^{b}$ & 0.89 & 6.90 \\
\hline Ustronie & $4.53^{\mathrm{a}}$ & $94.34^{b}$ & 0.62 & $24.40^{\mathrm{b}}$ & $3427^{a b}$ & $0.52^{\mathrm{a}}$ & 1.26 & 9.89 \\
\hline$p$-value & $0.037^{*}$ & $0.000 *$ & 0.068 & $0.000 *$ & $0.023 *$ & $0.000 *$ & 0.684 & 0.079 \\
\hline
\end{tabular}

* statistically significant $(\alpha=0.05) ; * *$ means followed by the same letters do not differ significantly at $(\alpha=0.05)$.

The nickel content in the soils under study ranged from 0.40 to $1.03 \mathrm{mg} \cdot \mathrm{kg}^{-1}$ and exhibited low variability $(\mathrm{CV}=18.92 \%)$ (Table 7$)$. Nickel is a heavy metal, small amounts of which were initially classified as beneficial to plants. In 1987, Brown et al. [31] discovered that nickel was necessary for plants, and the element was classified as a micronutrient.

The average manganese content in the topsoil of the allotment plots in Gorzów Wielkopolski was $50.33 \mathrm{mg} \cdot \mathrm{kg}^{-1}$. It ranged from 10.56 to $71.22 \mathrm{mg} \cdot \mathrm{kg}^{-1}$ and exhibited moderate variability $(\mathrm{CV}=40.78 \%)$ (Table 7$)$.

The average zinc content found in the allotment plots under study was $27.98 \mathrm{mg} \cdot \mathrm{kg}^{-1}$ and ranged from 4.22 to $52.02 \mathrm{mg} \cdot \mathrm{kg}^{-1}$ (Table 7). The soils of the allotment gardens in Gorzów Wielkopolski were characterised by moderate variability in the content of this metal. The most favourable soil zinc content for plant growth is $5.0-50.0 \mathrm{mg} \cdot \mathrm{dm}^{-3}$ [30]. The soils in the allotment gardens in Gorzów Wielkopolski had the recommended zinc content for the cultivation of plants.

The average content of soluble forms of cadmium in the soils of the allotment plots in Gorzów Wielkopolski was $0.37 \mathrm{mg} \cdot \mathrm{kg}^{-1}$. It ranged from 0.22 to $0.59 \mathrm{mg} \cdot \mathrm{kg}^{-1}$ and exhibited low variability $(\mathrm{CV}=24.56 \%$ ) (Table 7$)$.

The average content of chromium in the soils of the allotment plots in Gorzów Wielkopolski was $1.05 \mathrm{mg} \cdot \mathrm{kg}^{-1}$, and it was highly diversified $(\mathrm{CV}=54.97 \%)$ (Table 7). Both the lowest $\left(0.61 \mathrm{mg} \cdot \mathrm{kg}^{-1}\right)$ and the highest $\left(4.04 \mathrm{mg} \cdot \mathrm{kg}^{-1}\right)$ contents of this heavy metal were found in the soils of the Nowalijka AG.

The mean lead content in the soils of the allotment plots was $6.85 \mathrm{mg} \cdot \mathrm{kg}^{-1}$. It ranged from 3.46 to $16.89 \mathrm{mg} \cdot \mathrm{kg}^{-1}$, and it exhibited moderate variability ( $\mathrm{CV}=43.53 \%$ ) (Table 7$)$.

The content of five out of eight heavy metals significantly differentiated the examined allotment gardens (Table 8).

According to the Soil Quality Standards and Land Quality Standards Regulation of the Ministry of the Environment of 9 September 2002 (Official Journal No. 165, item 1359), land group ' $\mathrm{B}$ ' includes agricultural land (except land under ponds and ditches), forest, wooded and shrubby land, wasteland, as well as built-up and urbanised land (except industrial areas, open-pit mining areas, and municipal areas), for which the maximum permissible heavy metal contents in a layer of $0-30 \mathrm{~cm}$ are: $\mathrm{Cd}-4 \mathrm{mg} \cdot \mathrm{kg}^{-1} \mathrm{~d} . \mathrm{m} ., \mathrm{Cr}-150 \mathrm{mg} \cdot \mathrm{kg}^{-1} \mathrm{~d} . \mathrm{m}$., 
Cu-150 mg.kg ${ }^{-1}$ d.m., Ni-100 mg.kg ${ }^{-1}$ d.m., Pb-100 mg.kg ${ }^{-1}$ d.m., Zn-300 mg.kg ${ }^{-1}$ d.m. The contents of available heavy metals found in our research did not exceed these limits in the topsoil of the allotment gardens in Gorzów Wielkopolski.

The principal component analysis based on 24 soil parameters showed that the soils in the allotment gardens under study could be considered rather homogeneous. The allotment plots belonging to the six allotment gardens (AGs) did not form separate groups according to their affiliation with the individual AGs. The most prominent allotment plot was Metalowiec AG No. 2, where organic soils were found (Figure 2). The hierarchical cluster analysis confirmed the results of the PCA. It also showed that the group of allotment plots in the Tulipan AG was the most homogeneous (Figure 3). The analysis of variance based on the 24 soil parameters showed that the allotment gardens under study were significantly differentiated by only nine soil parameters, mainly the contents of metals, e.g., $\mathrm{Cd}, \mathrm{Fe}$, and Mn (Figure 4).

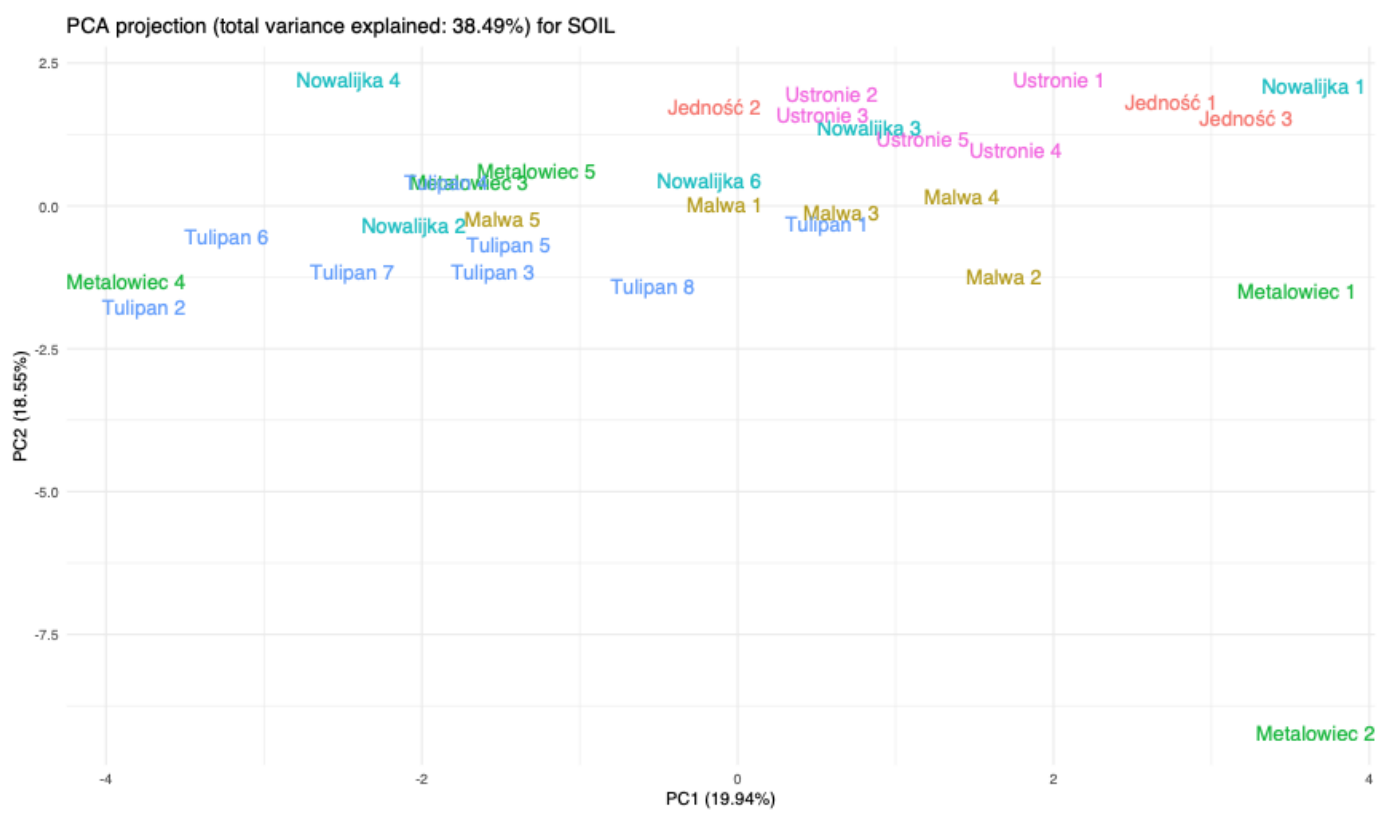

Figure 2. PCA relationship among studied allotment plots in respect to soil parameters.

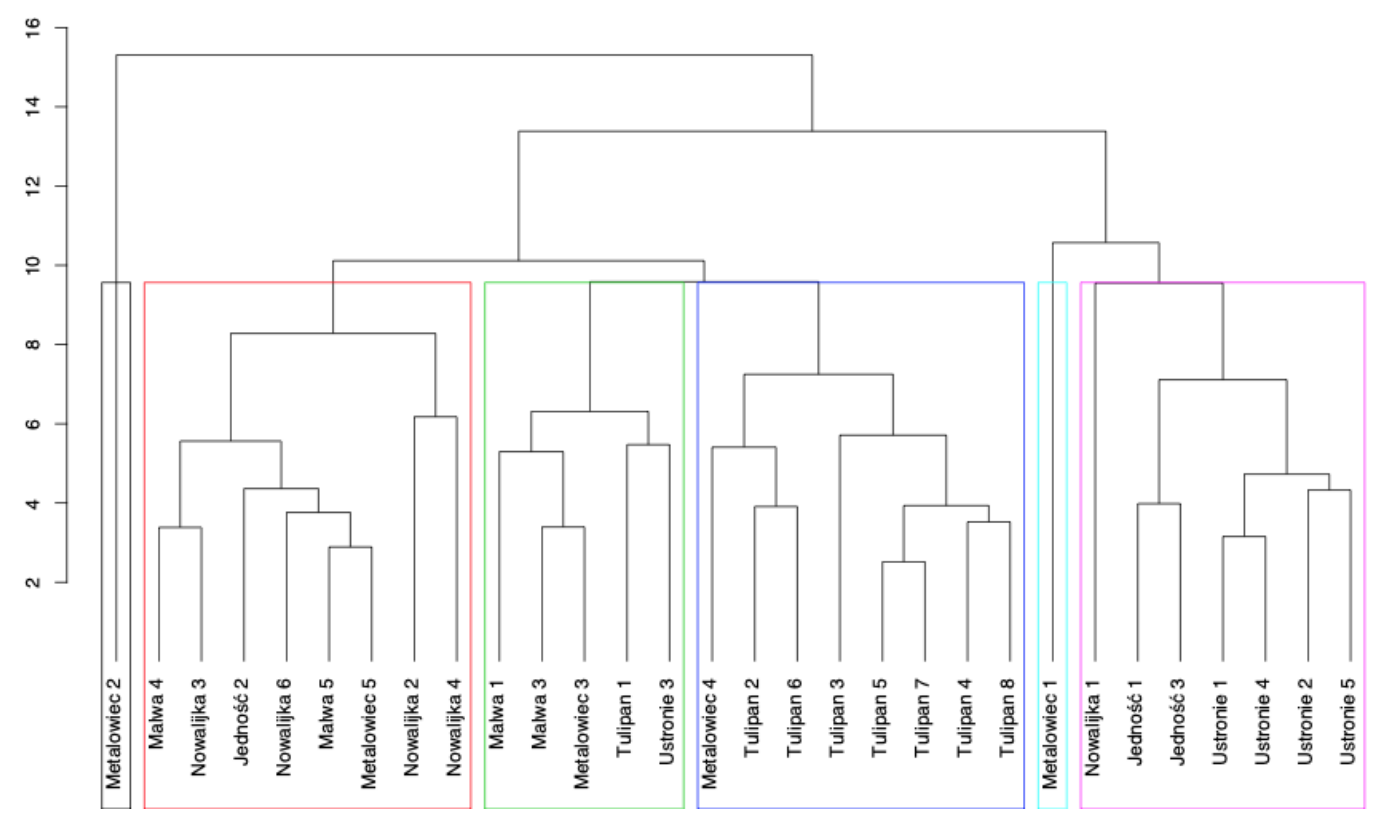

Figure 3. Dendrogram of 31 allotment plots calculated on the basis of soil parameters. 


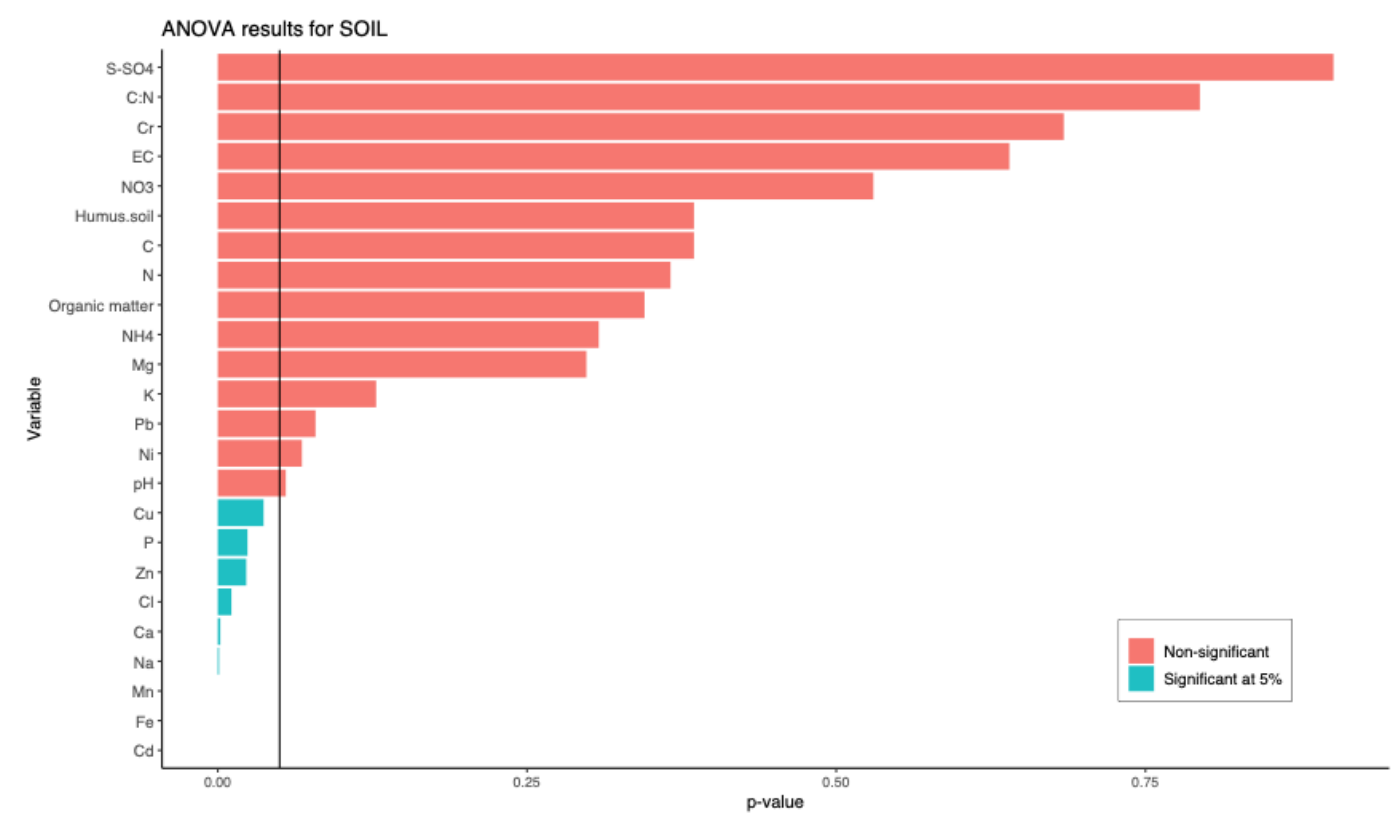

Figure 4. The results of ANOVA for soil parameters.

According to nutritionists' recommendations, vegetables are among the most desirable components of the human diet. However, apart from numerous nutrients such as vitamins, pectins, fibre, macronutrients, and micronutrients, they also contain heavy metals, which may be toxic to humans. The accumulation of heavy metals in edible parts of vegetables depends on various factors, including cultivation methods and environmental factors.

The carrot (Daucus carota subsp. sativus) was selected for tests in our study, because this vegetable was commonly grown in the allotment gardens in Gorzów Wielkopolski.

The average extract content in the carrot roots analysed in our study was $8.89{ }^{\circ} \mathrm{Bx}$ (6.0-13.1) (Table 9). Kumar et al. [32] found that the extract content in the carrot roots ranged from 9.14 to $9.48^{\circ} \mathrm{Bx}$. The content of nitrate in the carrot roots collected from the allotment plots in Gorzów Wielkopolski ranged from 60 to $616 \mathrm{mg} \mathrm{NO}_{3}{ }^{-}$per $\mathrm{kg}$ of fresh weight (average content $305.90 \mathrm{mg}$ ) (Table 9). According to Wierzbowska et al. [33], the content of nitrate in carrot roots collected from integrated and organic cropping areas did not exceed $200 \mathrm{mg} \mathrm{NO}_{3}{ }^{-}$per $\mathrm{kg}$ of fresh weight. The average sugar content in the carrot roots grown in the allotment gardens in Gorzów Wielkopolski was 7.07\% (3.90-10.20) (Table 9). Baranski et al. [34] analysed more than 100 carrot cultivars and noted that the sugar content ranged from $5.1 \%$ to $13.6 \%$. In our study (Table 9 ), the average content of $\beta$-carotene in the carrot roots was almost $12 \mathrm{mg}$ per $100 \mathrm{~g}$ of fresh weight (3.20-18.70 mg), whereas Fikselová et al. [35] noted 13.4-26.3 mg per $100 \mathrm{~g}$ of fresh weight. The content of sugars and $\beta$-carotene in the carrot roots collected from the gardens in Gorzów Wielkopolski can be considered satisfactory.

Table 9. The content of dry matter, extract, nitrate, sugar, and $\beta$-carotene in the roots of Daucus carota subsp. sativus growing in 21 allotment plots of Gorzów Wielkopolski.

\begin{tabular}{|c|c|c|c|c|c|}
\hline Statistics & $\begin{array}{c}\text { Dry Matter } \\
\text { of Roots }(\%)\end{array}$ & $\begin{array}{c}\text { Extract } \\
\left({ }^{\circ} \mathrm{Bx}\right)\end{array}$ & $\begin{array}{c}\text { Nitrate } \\
\left(\mathrm{mg} \cdot \mathrm{kg}^{-1} \text { f.m) }\right.\end{array}$ & $\begin{array}{c}\text { Sugar } \\
(\%)\end{array}$ & $\begin{array}{c}\beta \text {-Carotene } \\
\text { (mg.100 g f.m) }\end{array}$ \\
\hline $\min$. & 7.80 & 6.00 & 60.00 & 3.90 & 3.20 \\
\hline $\max$ & 14.60 & 13.10 & 616.00 & 10.20 & 18.70 \\
\hline mean & 10.70 & 8.89 & 305.90 & 7.07 & 11.75 \\
\hline SD & 1.92 & 1.69 & 144.84 & 1.86 & 4.43 \\
\hline CV (\%) & 17.95 & 18.97 & 47.35 & 26.27 & 37.75 \\
\hline
\end{tabular}


The dry matter content in the carrot roots ranged from $7.80-14.60 \%$ (average content $11.06 \%$ ) (Table 9). Fikselová et al. [35] observed that the dry matter content in the roots of four carrot cultivars was $8.4-14.3 \%$. From the carrot roots parameters described above, only the extract content differentiated significantly the studied allotment gardens (Table 10).

Table 10. The content of dry matter, extract, nitrate, sugar, and $\beta$-carotene in the roots of Daucus carota subsp. sativus growing in six allotment gardens of Gorzów Wielkopolski.

\begin{tabular}{|c|c|c|c|c|c|}
\hline AGs & $\begin{array}{c}\text { Dry Matter } \\
\text { of Roots (\%) }\end{array}$ & $\begin{array}{c}\text { Extract } \\
\left({ }^{\circ} \mathbf{B x}\right)\end{array}$ & $\begin{array}{c}\text { Nitrate } \\
\left(\mathrm{mg} \cdot \mathrm{kg}^{-1} \text { f.m) }\right.\end{array}$ & $\begin{array}{l}\text { Sugar } \\
(\%)\end{array}$ & $\begin{array}{c}\beta \text {-Carotene } \\
\text { (mg.100 g f.m) }\end{array}$ \\
\hline Jedność & 9.30 & $6.90^{b, * *}$ & 259.00 & 6.10 & 8.10 \\
\hline Malwa & 10.03 & $7.83^{a b}$ & 327.00 & 5.60 & 9.47 \\
\hline Metalowiec & 12.90 & $11.53^{\mathrm{a}}$ & 443.33 & 8.00 & 15.40 \\
\hline Nowalijka & 10.73 & $8.77^{a b}$ & 348.67 & 7.20 & 14.13 \\
\hline Tulipan & 11.04 & $8.87^{\mathrm{ab}}$ & 278.43 & 7.56 & 13.09 \\
\hline Ustronie & 11.77 & $8.80^{a b}$ & 200.00 & 7.00 & 7.30 \\
\hline$p$-value & 0.228 & $0.026^{*}$ & 0.472 & 0.675 & 0.119 \\
\hline
\end{tabular}

When growing vegetables in mineral soils, it is important that the edible parts of vegetables have the lowest possible content of toxic metals such as $\mathrm{Cd}$ and $\mathrm{Pb}$. It is also important for human nutrition that the edible parts of vegetables are rich in $\mathrm{Fe}, \mathrm{Cu}, \mathrm{Cr}, \mathrm{Mn}$, and $\mathrm{Zn}$.

The PCA based on the content of eight heavy metals in the carrot roots showed high homogeneity of the allotment plots in terms of the traits under analysis (Figure 5). The hierarchical cluster analysis confirmed the PCA results (Figure 6). The analysis of variance for eight heavy metals showed that the allotment gardens were significantly differentiated only by the content of toxic cadmium in the carrot roots (Figure 7, Table 11).

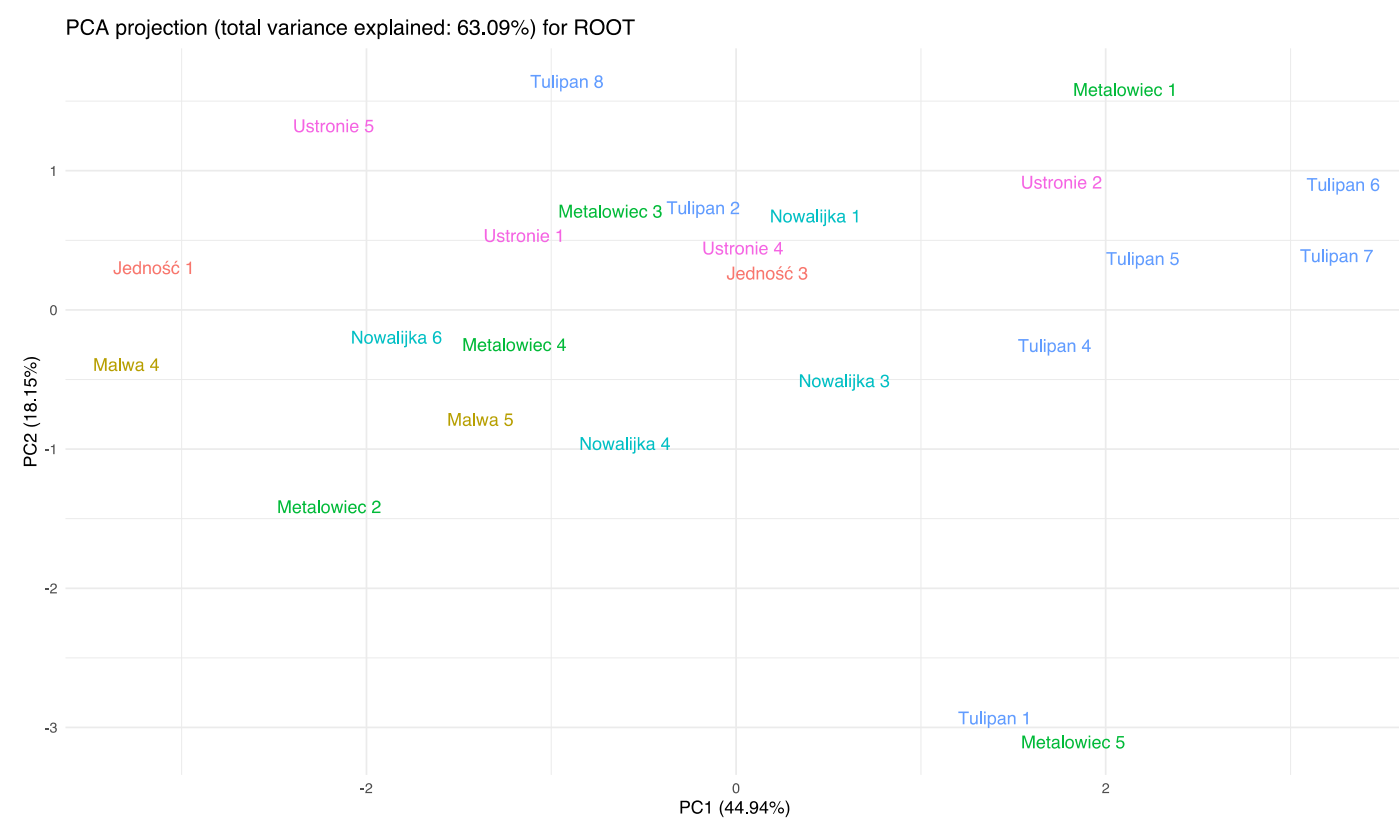

Figure 5. PCA relationship among studied allotment plots in respect to root parameters. 


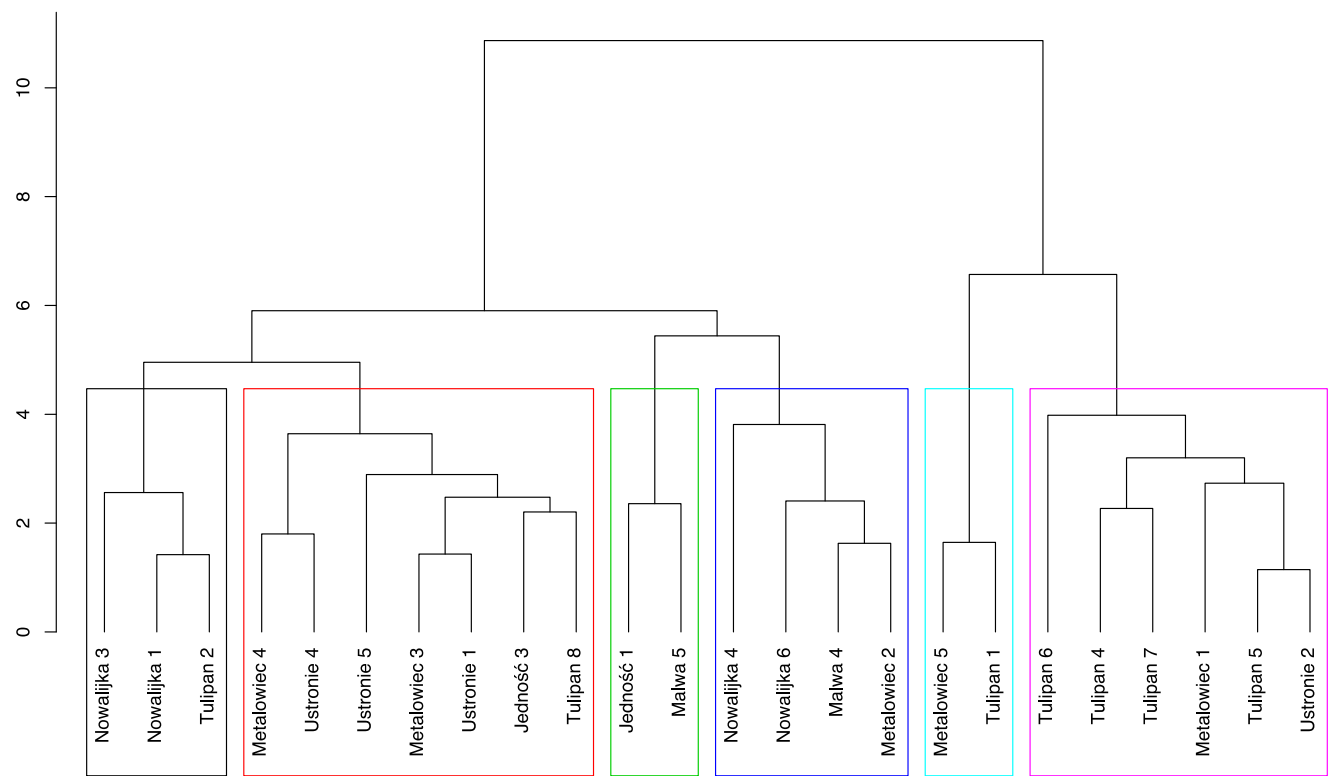

Figure 6. Dendrogram of 31 allotment plots calculated on the basis of root parameters.

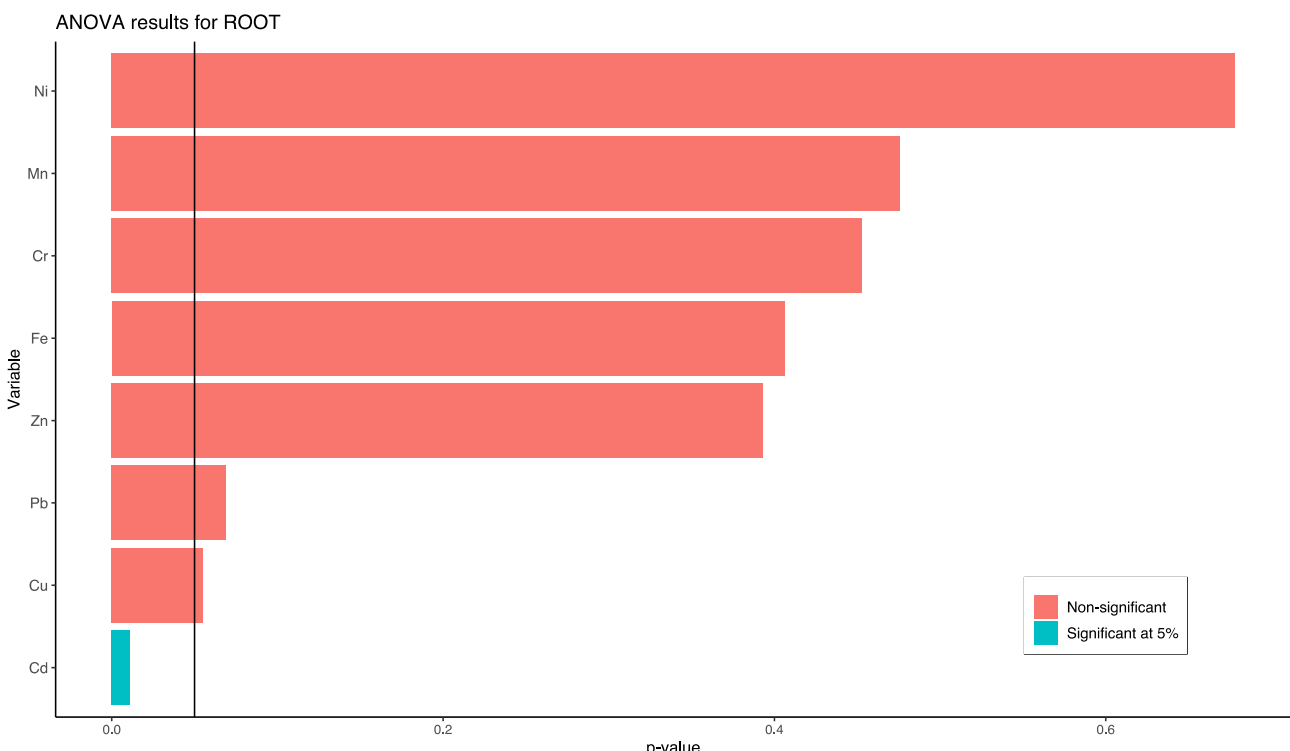

Figure 7. The results of ANOVA for root parameters.

Table 11. The content of heavy metals in the roots of Daucus carota subsp. sativus growing in six allotment gardens of Gorzów Wielkopolski.

\begin{tabular}{|c|c|c|c|c|c|c|c|c|}
\hline \multirow{2}{*}{ AGs } & \multicolumn{8}{|c|}{ Content $\mathrm{mg} \cdot \mathrm{kg}^{-1} \mathrm{~d} . \mathrm{m}}$. \\
\hline & $\mathrm{Cu}$ & $\mathrm{Fe}$ & $\mathbf{N i}$ & Mn & $\mathrm{Zn}$ & $\mathrm{Cd}$ & $\mathrm{Cr}$ & $\mathrm{Pb}$ \\
\hline Jedność & 3.17 & 129.67 & 3.46 & 9.60 & 20.59 & $\begin{array}{c}3.00 \\
a * *\end{array}$ & 6.41 & 6.13 \\
\hline Malwa & 2.17 & 171.97 & 3.57 & 7.77 & 18.71 & $2.73^{a b}$ & 7.49 & 6.23 \\
\hline Metalowiec & 3.07 & 202.72 & 3.42 & 10.13 & 22.13 & $1.79 \mathrm{ab}$ & 5.85 & 5.53 \\
\hline Nowalijka & 2.65 & 112.97 & 3.43 & 13.90 & 21.97 & $1.73^{\mathrm{ab}}$ & 6.32 & 5.63 \\
\hline Tulipan & 3.78 & 165.72 & 3.22 & 11.64 & 24.90 & $1.41^{\mathrm{b}}$ & 5.02 & 4.83 \\
\hline Ustronie & 3.63 & 174.11 & 3.49 & 7.80 & 25.47 & $1.86^{\mathrm{ab}}$ & 6.53 & 6.19 \\
\hline$p$-value & 0.055 & 0.406 & 0.678 & 0.476 & 0.393 & 0.011 * & 0.453 & 0.069 \\
\hline
\end{tabular}


It is important for consumers that carrot roots should have high nutritional value and be free from significant contamination with heavy metals. However, in the context of plant nutrition, it is also important to examine the aerial part of the plant, i.e., carrot leaves. Therefore, both carrot roots and shoots were analysed in our study, with a special focus on the content of the toxic heavy metals cadmium and lead.

The average contents of heavy metals in the carrot roots were: $\mathrm{Cu}-3.24 \mathrm{mg} \cdot \mathrm{kg}^{-1}, \mathrm{Fe}-$ $163.55 \mathrm{mg} \cdot \mathrm{kg}^{-1}, \mathrm{Ni}-3.39 \mathrm{mg} \cdot \mathrm{kg}^{-1}, \mathrm{Mn}-10.57 \mathrm{mg} \cdot \mathrm{kg}^{-1}, \mathrm{Zn}-23.06 \mathrm{mg} \cdot \mathrm{kg}^{-1}, \mathrm{Cd}-1.86 \mathrm{mg} \cdot \mathrm{kg}^{-1}$, $\mathrm{Cr}-5.99 \mathrm{mg} \cdot \mathrm{kg}^{-1}$ and $\mathrm{Pb}-5.56 \mathrm{mg} \cdot \mathrm{kg}^{-1}$. The content of $\mathrm{Cu}, \mathrm{Ni}, \mathrm{Zn}, \mathrm{Cd}$, and $\mathrm{Pb}$ in the carrot roots was characterised by low variability (Table 12). The content of Fe, Mn, Cd, and $\mathrm{Cr}$ in the carrot roots was characterised by moderate variability. The average content of individual heavy metals in the carrot roots was ordered as follows: $\mathrm{Fe}>\mathrm{Zn}>\mathrm{Mn}>\mathrm{Cr}>\mathrm{Pb}>\mathrm{Ni}>\mathrm{Cu}$ $>$ Cd.

Table 12. The content of heavy metals in the roots of Daucus carota subsp. sativus growing in 24 allotment plots of Gorzów Wielkopolski.

\begin{tabular}{ccccccccc}
\hline \multirow{2}{*}{ Statistics } & \multicolumn{7}{c}{ Content $\mathbf{m g} \cdot \mathbf{k g} \mathbf{- 1}^{\mathbf{1}} \mathbf{d . m}}$. \\
\cline { 2 - 9 } & $\mathbf{C u}$ & $\mathbf{F e}$ & $\mathbf{N i}$ & $\mathbf{M n}$ & $\mathbf{Z n}$ & $\mathbf{C d}$ & $\mathbf{C r}$ & $\mathbf{P b}$ \\
\hline min. & 2.16 & 73.73 & 2.64 & 5.26 & 17.04 & 1.07 & 3.07 & 4.26 \\
max. & 5.06 & 332.05 & 3.98 & 22.79 & 32.17 & 3.92 & 8.86 & 7.12 \\
mean & 3.24 & 163.55 & 3.39 & 10.57 & 23.06 & 1.86 & 5.99 & 5.56 \\
SD & 0.79 & 61.40 & 0.30 & 4.51 & 4.34 & 0.66 & 1.65 & 0.84 \\
CV $(\%)$ & 24.53 & 37.54 & 8.90 & 42.71 & 18.84 & 35.35 & 27.50 & 15.01 \\
\hline
\end{tabular}

As far as the aerial part of carrots is concerned, the series of the average content of individual heavy metals was similar, except for zinc and manganese content: $\mathrm{Fe}>\mathrm{Mn}>\mathrm{Zn}>\mathrm{Cr}$ $>\mathrm{Pb}>\mathrm{Ni}>\mathrm{Cu}>\mathrm{Cd}$ (Table 13). The average contents of individual heavy metals in the aerial part of the carrots amounted to: $\mathrm{Cu}-5.30 \mathrm{mg} \cdot \mathrm{kg}^{-1}, \mathrm{Fe}-506.57 \mathrm{mg} \cdot \mathrm{kg}^{-1}, \mathrm{Ni}-5.35 \mathrm{mg} \cdot \mathrm{kg}^{-1}$, $\mathrm{Mn}-75.29 \mathrm{mg} \cdot \mathrm{kg}^{-1}, \mathrm{Zn}-42.11 \mathrm{mg} \cdot \mathrm{kg}^{-1}, \mathrm{Cd}-2.55 \mathrm{mg} \cdot \mathrm{kg}^{-1}, \mathrm{Cr}-15.25 \mathrm{mg} \cdot \mathrm{kg}^{-1}$, and $\mathrm{Pb}-$ $10.30 \mathrm{mg} \cdot \mathrm{kg}^{-1}$. The content of $\mathrm{Ni}, \mathrm{Zn}, \mathrm{Cd}, \mathrm{Cr}$, and $\mathrm{Pb}$ in the aerial part of the carrots was characterised by low variability, whereas the content of Fe and Mn was characterised by moderate variability. There was high variability in the $\mathrm{Cu}$ content (Table 13). The analysis of variance for eight heavy metals showed that the allotment gardens were significantly differentiated by the content of $\mathrm{Fe}, \mathrm{Mn}$, and $\mathrm{Cr}$ in aboveground part of carrots (Table 14).

Table 13. The content of heavy metals in the aboveground part of Daucus carota subsp. sativus growing in 24 allotment plots of Gorzów Wielkopolski.

\begin{tabular}{ccccccccc}
\hline \multirow{2}{*}{ Statistics } & \multicolumn{8}{c}{ Content $\mathbf{~ m g} \cdot \mathbf{k g} \mathbf{- 1}$ d.m. } \\
\cline { 2 - 10 } & $\mathbf{C u}$ & $\mathbf{F e}$ & $\mathbf{N i}$ & $\mathbf{M n}$ & $\mathbf{Z n}$ & $\mathbf{C d}$ & $\mathbf{C r}$ & $\mathbf{P b}$ \\
\hline min. & 3.38 & 172.78 & 4.60 & 27.55 & 24.19 & 2.06 & 11.67 & 8.65 \\
max. & 20.52 & 836.28 & 6.08 & 130.39 & 63.38 & 3.54 & 19.83 & 12.31 \\
mean & 5.30 & 506.57 & 5.35 & 75.29 & 42.11 & 2.55 & 15.25 & 10.30 \\
SD & 3.25 & 196.46 & 0.39 & 32.38 & 10.04 & 0.32 & 2.33 & 0.95 \\
CV $(\%)$ & 61.23 & 38.78 & 7.38 & 43.01 & 23.86 & 12.76 & 15.25 & 9.21 \\
\hline
\end{tabular}

The analysis of the average content of individual heavy metals in the carrots showed that there were higher amounts of these elements in the aerial part of the plants than in their roots. Taking the dry matter content in the carrot roots into account (Tables 9 and 10), the results of measurements of cadmium and lead content in the roots were converted into their fresh matter content. After conversion, the cadmium content in the roots ranged from 0.11 to $0.35 \mathrm{mg} \cdot \mathrm{kg}^{-1}$ fresh matter (standard $0.1 \mathrm{mg} \cdot \mathrm{kg}^{-1}$ fresh matter), whereas the lead content ranged from 0.42 to $0.85 \mathrm{mg} \cdot \mathrm{kg}^{-1}$ fresh matter (standard $0.1 \mathrm{mg} \cdot \mathrm{kg}^{-1}$ fresh matter). The comparison of the results of measurements of cadmium and lead content in the carrots 
with the applicable EU standards regarding the maximum levels of these elements [36] showed that they were exceeded in all the samples.

Table 14. The content of heavy metals in the aboveground part of Daucus carota subsp. sativus growing in six allotment gardens of Gorzów Wielkopolski.

\begin{tabular}{|c|c|c|c|c|c|c|c|c|}
\hline \multirow{2}{*}{ AGs } & \multicolumn{8}{|c|}{ Content $\mathrm{mg} \cdot \mathrm{kg}^{-1}$ d.m. } \\
\hline & $\mathrm{Cu}$ & $\mathrm{Fe}$ & $\mathbf{N i}$ & Mn & $\mathrm{Zn}$ & $\mathrm{Cd}$ & $\mathrm{Cr}$ & $\mathrm{Pb}$ \\
\hline Jedność & 4.98 & $388.49^{a b * *}$ & 5.48 & $34.61^{\mathrm{c}}$ & 44.28 & 2.35 & $14.07^{\mathrm{a}}$ & 9.69 \\
\hline Malwa & 4.52 & $401.36^{\mathrm{ab}}$ & 4.80 & $79.21^{\mathrm{abc}}$ & 44.90 & 2.30 & $15.95^{\mathrm{a}}$ & 8.94 \\
\hline Metalowiec & 4.01 & $481.46^{\mathrm{ab}}$ & 5.38 & $60.28^{b c}$ & 43.92 & 2.68 & $15.53^{\mathrm{a}}$ & 10.64 \\
\hline Nowalijka & 4.70 & $260.27^{b}$ & 5.15 & $111.25^{\mathrm{a}}$ & 30.02 & 2.75 & $13.04^{\mathrm{a}}$ & 10.03 \\
\hline Tulipan & 4.58 & $708.14^{\mathrm{a}}$ & 5.61 & $95.04^{a b}$ & 43.97 & 2.49 & $17.20^{\mathrm{a}}$ & 10.76 \\
\hline Ustronie & 9.33 & $543.16^{\mathrm{ab}}$ & 5.26 & $41.88^{c}$ & 46.18 & 2.46 & $13.95^{\mathrm{a}}$ & 10.32 \\
\hline$p$-value & 0.195 & $0.002 *$ & 0.137 & $0.001 *$ & 0.235 & 0.504 & $0.048^{*}$ & 0.197 \\
\hline
\end{tabular}

The correlation coefficient between the soil cadmium content and the carrot root cadmium content was -0.2895 . This correlation was not statistically significant $(p$-value $=0.2$ ). There was also a statistically insignificant correlation between the soil lead content and the carrot root lead content $(p$-value $=0.9$, correlation coefficient -0.0139 ).

Many authors claim that vegetables take up considerable amounts of cadmium and lead from soil. Lettuce, radish, spinach, parsley, and carrots are the vegetables which accumulate excessive amounts of cadmium and lead [37].

Various external factors which are more or less harmful to the soil environment also affect soils in urbanised areas. The local diversification of these factors is so great that it is often difficult to assign the results of investigations to the phenomena occurring in soil and its vicinity.

The soil $\mathrm{pH}$ is one of the main factors influencing the form of occurrence and availability of heavy metals for plants [38]. It is a decisive factor influencing the strength of metal bonding by organic matter and mineral compounds [39]. As there is increased concentration of heavy metals in acidic soils, it may lead to their excessive uptake by plants $[40,41]$. There is also increased concentration of some metals (e.g., lead) in alkaline soils [42]. The content of available forms of heavy metals (especially toxic metals) in acidic soils can be reduced by liming.

The analysis of variance showed that there was no statistically significant relationship between the soil $\mathrm{pH}$ and the average cadmium level in the soil ( $p$-value $=0.683)$, nor was there a significant relationship between the soil $\mathrm{pH}$ and the average lead content in the soil $(p$-value $=0.582)$.

The mean $\mathrm{pH}_{\mathrm{H} 2 \mathrm{O}}$ of the soil in the allotment plots in Gorzów Wielkopolski was 7.44. This value was too high for most of the plant species grown in these gardens. The optimum $\mathrm{pH}$ for vegetables grown in allotment gardens should be 6.0-6.5. The higher soil $\mathrm{pH}$ was caused by excessive doses of calcium and calcium-magnesium fertilizers applied by the allotment garden users every year (data provided by the allotment garden users in a questionnaire survey).

Soils located in urban areas may also be alkalised by products of coal combustion and by sodium chloride and calcium chloride used to de-ice roads [43]. The authors of studies conducted in other Polish cities also observed soil alkalisation, e.g., in Siedlce [44], Warsaw [45], Poznań [46], and Puławy [47].

Other soil factors reducing the amount of heavy metal forms available to plants are organic substance and soil humus. Humus significantly detoxifies soil from heavy metals, because it binds $\mathrm{Cr}^{3+}, \mathrm{Fe}^{3+}, \mathrm{Pb}^{2+}$, and $\mathrm{Ni}^{2+}$ ions very strongly and binds less strongly with $\mathrm{Mn}^{2+}$ and $\mathrm{Zn}^{2+}$ ions. In consequence, these metals are less accessible and less toxic to plants $[48,49]$. 
There was no statistically significant relation between the organic carbon content and soil cadmium $(p$-value $=0.944)$ and lead content $(p$-value $=0.924)$. Additionally, the soil organic carbon content had no significant effect on cadmium and lead content in the carrot roots, as evidenced by correlation coefficients and $p$-value: soil organic carbon (SOC) vs. carrot root $\mathrm{Cd}=0.047$ ( $p$-value $=0.826)$ and SOC vs. carrot root $\mathrm{Pb}=0.179(p$-value $=0.403)$.

The study showed that, in order to reduce the uptake of cadmium and lead by carrots, which are commonly grown in allotment gardens, the soil $\mathrm{pH}$ should be controlled and maintained at a neutral level. When the soil $\mathrm{pH}$ is maintained at this optimal level, the availability of cadmium and lead to plants is the lowest. It is also necessary to enrich soil with organic carbon, which detoxifies cadmium and lead and thus reduces the uptake of these metals by plants [49].

If cadmium and lead content in the aerial part is higher than in the root, it may be caused not only by soil contamination but also by another source, e.g., fallout. However, this factor was not analysed in our study.

During our studies, we did not reveal evident differences between six allotment gardens widespread in the city of Gorzów Wielkopolski. Hence, we can assume that the detected high level of variability in some soil and carrot characteristics among plots may be associated with individual cultivation practices of plot holders.

\section{Conclusions}

The soils in the allotment gardens in the city of Gorzów Wielkopolski were abundant in nutrients for growing vegetables. The soils had high content of calcium, magnesium, and phosphorus. The soil $\mathrm{pH}$ in the vegetable cropping areas was too high. The soils in allotment gardens must be regularly fertilized with nitrogen every year. Decisions about fertilization with other nutrients should be taken annually after a chemical analysis of the soil. Most of the soils in the allotment gardens under study had low sodium content. High content of this element may result in poor quality and lower yield of vegetables. Although the topsoil was not contaminated with cadmium, chromium, or lead (available forms), the permissible limit of cadmium and lead content was exceeded in the edible part of the carrots. In order to detoxify heavy metals in the soil and limit the uptake of cadmium, chromium, and lead by carrots, it is necessary to adjust the $\mathrm{pH}$ of the soil to neutral and enrich it with organic carbon. To ensure the safety of consumers, it seems necessary to constantly monitor the heavy metal content in the edible parts of vegetables, especially those grown in urban areas.

Author Contributions: Conceptualisation, L.B., M.B. and A.M.; methodology, M.B., T.S. and L.B.; statistical analysis, T.G.; investigation, M.B. and T.S.; writing-original draft preparation, M.B., L.B. and L.P.; writing-review and editing, L.B.; visualisation, K.F.; project administration, L.P.; funding acquisition, L.P. All authors have read and agreed to the published version of the manuscript.

Funding: The study was financed by the National Science Centre, Poland (grant No. 2017/25/Z/HS4/ 03048). This project was financed from the EU Horizon 2020 research and innovation programme (GA No. 730254) under the JPI Urban Europe's call 'SUGI-FWE Nexus'.

Institutional Review Board Statement: Not applicable.

Informed Consent Statement: Not applicable.

Data Availability Statement: Not applicable.

Acknowledgments: The authors would like to thank the Polish Allotment Owners' Association, Gorzów Wielkopolski District and all the allotment gardeners who actively participated in the project.

Conflicts of Interest: The authors declare no conflict of interest. The funders had no role in the design of the study; in the collection, analyses, or interpretation of data; in the writing of the manuscript, or in the decision to publish the results. 


\section{References}

1. Artmann, M.; Sartison, K. The role of urban agriculture as a nature-based solution: A review for developing a systemic assessment framework. Sustainability 2018, 10, 1937. [CrossRef]

2. Sowińska-Świerkosz, B.; Michalik-Śnieżek, M.; Bieske-Matejak, A. Can Allotment Gardens (AGs) Be Considered an Example of Nature-Based Solutions (NBS) Based on the Use of Historical Green Infrastructure? Sustainability 2021, 13, 835. [CrossRef]

3. Central Statistical Office. Statistical Yearbook of Agriculture 2017; Central Statistical Office: Warszaw, Poland, 2017.

4. Bellows, A.C. One Hundred Years of Allotment Gardens in Poland. Food Foodways 2004, 12, 247-276. [CrossRef]

5. Ackerman, K.; Conard, M.; Culligan, P.; Plunz, R.; Sutto, M.-P.; Whittinghil, L. Sustainable Food Systems for Future Cities: The Potential of Urban Agriculture. Econ. Soc. Rev. 2014, 45, 189-206.

6. Edmondson, J.L.; Davies, Z.G.; Gaston, K.J.; Leake, J.R. Urban Cultivation in Allotments Maintains Soil Qualities Adversely Affected by Conventional Agriculture. J. Appl. Ecol. 2014, 51, 880-889. [CrossRef] [PubMed]

7. Bretzel, F.; Calderisi, M.; Scatena, M.; Pini, R. Soil Quality Is Key for Planning and Managing Urban Allotments Intended for the Sustainable Production of Home-Consumption Vegetables. Environ. Sci. Pollut. Res. 2016, 23, 17753-17760. [CrossRef] [PubMed]

8. Palmer, L. Urban Agriculture Growth in US Cities. Nat. Sustain. 2018, 1, 5-7. [CrossRef]

9. Sanyé-Mengual, E.; Gasperi, D.; Michelon, N.; Orsini, F.; Ponchia, G.; Gianquinto, G. Eco-Efficiency Assessment and Food Security Potential of Home Gardening: A Case Study in Padua, Italy. Sustainability 2018, 10, 2124. [CrossRef]

10. Weber, A.M.; Mawodza, T.; Sarkar, B.; Menon, M. Assessment of Potentially Toxic Trace Element Contamination in Urban Allotment Soils and Their Uptake by Onions: A Preliminary Case Study from Sheffield, England. Ecotoxicol. Environ. Saf. 2019, 170, 156-165. [CrossRef]

11. Antisari, L.V.; Orsini, F.; Marchetti, L.; Vianello, G.; Gianquinto, G. Heavy Metal Accumulation in Vegetables Grown in Urban Gardens. Agron. Sustain. Dev. 2015, 35, 1139-1147. [CrossRef]

12. Noli, F.; Tsamos, P. Concentration of Heavy Metals and Trace Elements in Soils, Waters and Vegetables and Assessment of Health Risk in the Vicinity of a Lignite-Fired Power Plant. Sci. Total Environ. 2016, 563-564, 377-385. [CrossRef]

13. Kondracki, J. Geografia Polski: Mezoregiony Fizycznogeograficzne; Wydawnictwo Naukowe PWN: Warszaw, Poland, 1994.

14. Detailed Geological Map of Poland 1:50,000, Sheet: Gorzów Wielkopolski (387); Polish Geological Insitute, Ministry of Environment: Warsaw, Poland, 2009.

15. Detailed Geological Map of Poland 1:50,000, Sheet: Santok (388); Polish Geological Insitute, Ministry of Environment: Warsaw, Poland, 2003.

16. Fedeńczak, K.; Poniży, L. The importance of allotment garden ecosystem services for adaptation to climate change-examples from Gorzów Wlkp. In Landscape Architecture in the Face of Climate Change; Tow. Nauk. W Tor.: Toruń, Poland, 2020; pp. 147-160.

17. IMGW-Państwowy Instytut Badawczy. Rocznik Meteorologiczny. 2019. Available online: http://danepubliczne.imgw.pl/data/ arch/ost_meteo (accessed on 25 August 2021).

18. Golcz, A. Soil salinity and acidity. In Soil Sickness (Research Methods in Plant Sciences); Narwal, S.S., Politycka, B., Fengzhi, W.U., Sampietro, D.A., Eds.; Studium Press LLC: Huston, TX, USA, 2011; Volume 3, pp. 43-53.

19. Kozik, E.; Golcz, A. Plamt nutrients. In Soil Sickness (Research Methods in Plant Sciences); Narwal, S.S., Politycka, B., Fengzhi, W.U., Sampietro, D.A., Eds.; Studium Press LLC: Huston, TX, USA, 2011; Volume 3, pp. 21-41.

20. Golcz, A.; Bosiacki, M. Soil Organic Matter. In Soil Sickness (Research Methods in Plant Sciences); Narwal, S.S., Politycka, B., Fengzhi, W.U., Sampietro, D.A., Eds.; Studium Press LLC: Huston, TX, USA, 2011; Volume 3, pp. 68-78.

21. Nowosielski, O. Zasady Opracowywania Zaleceń Nawozowoch w Ogrodnictwie; Państwowe Wydawnictwo Rolnicze i Leśne: Warszaw, Poland, 1988.

22. Bosiacki, M.; Roszyk, J. The comparing methods of mineralization of plant material on the content of heavy metals. Apar. Badaw. I Dydakt. 2010, XIV, 37-41.

23. Yemm, E.W.; Willis, A.J. The Estimation of Carbohydrates in Plant Extracts by Anthrone. Biochem. J. 1954, 57, 508-514. [CrossRef]

24. Polish Committee for Standardization. Owoce, Warzywa i Ich Przetwory-Oznaczanie Zawartości Azotynów i Azotanów; PN-92/A75112; Polish Committee for Standardization: Warszaw, Poland, 2013.

25. Johnson, S.C. Hierarchical Clustering Schemes. Psychometrika 1967, 32, 241-254. [CrossRef] [PubMed]

26. Abdi, H.; Edelman, B.; Valentin, D.; Dowling, W.J. Experimental Design and Analysis for Psychology; Oxford University Press: Oxford, UK, 2009.

27. R: Core Team. R: A Language and Environment for Statistical Computing; The R Project for Statistical Computing: Vienna, Austria, 2019.

28. Komosa, A.; Breś, W.; Golcz, A.; Kozik, E.; Tyksiński, W. Żywienie Roślin Ogrodniczych; Wydawnictwo Uniwersytetu Przyrodniczego w Poznaniu: Poznań, Poland, 2009.

29. Filipek-Mazur, B.; Tabak, M. Soil, Traffic Pollution, Copper, Zinc, Chromium, Sequential Extraction. Ecol. Chem. Eng. A 2011, 18, 1533-1538.

30. Sady, W. Fertilization of Field-Grown Vegetables; Plantpress: Kraków, Poland, 2000.

31. Brown, P.H.; Welch, R.M.; Cary, E.E. Nickel: A Micronutrient Essential for Higher Plants. Plant. Physiol. 1987, 85, 801-803. [CrossRef] [PubMed]

32. Kumar, S.; Nei, M.; Dudley, J.; Tamura, K. MEGA: A Biologist-Centric Software for Evolutionary Analysis of DNA and Protein Sequences. Brief. Bioinform. 2008, 9, 299-306. [CrossRef] 
33. Wierzbowska, J.; Cwalina-Ambroziak, B.; Głosek-Sobieraj, M.; Sienkiewicz, S. Yield and Mineral Content of Edible Carrot Depending on Cultivation and Plant Protection Methods. Acta Sci. Pol. Hortorum Cultus 2017, 16, 75-86.

34. Baranski, R.; Allender, C.; Klimek-Chodacka, M. Towards Better Tasting and More Nutritious Carrots: Carotenoid and Sugar Content Variation in Carrot Genetic Resources. Food Res. Int. 2012, 47, 182-187. [CrossRef]

35. Fikselová, M.; Mareček, J.; Mellen, M. Carotenes Content in Carrot Roots (Daucus Carota L.) as Affected by Cultivation and Storage. J. Fruit Ornam. Plant. Res. 2010, 73, 47-54. [CrossRef]

36. European Commission. Commission regulation (EC) No. 1881/2006 setting maximum levels for certain contaminants in foodstuffs. Off. J. Eur. Union 2006, 364, 5-24.

37. Dudka, S.; Piotrowska, M.; Chlopecka, A.; Witek, T. Trace Metal Contamination of Soils and Crop Plants by the Mining and Smelting Industry in Upper Silesia, South Poland. J. Geochem. Explor. 1995, 52, 237-250. [CrossRef]

38. Kabata-Pendians, A.; Pendias, H. Biochemistry Trace Elements; Wydawnictwo Naukowe PWN: Warszaw, Poland, 1999.

39. Herms, U.; Brümmer, G. Influencing factors of heavy metal solubility and retention in soil. Pflanzenern Bonenk 1991, 147, 400-424. [CrossRef]

40. Alloway, B.J.; Ayres, D.C. Chemical Pollution Base; PWN: Warszaw, Poland, 1999.

41. Blake, L.; Goulding, K.W.T. Influencing Factors of Heavy Metal Solubility and Retention in Soil. Plant. Soil 2002, $240,235-251$. [CrossRef]

42. Tyler, G.; Olsson, T. Concentrations of 60 Elements in the Soil Solution as Related to the Soil Acidity: Solubility of 60 Elements and Soil Acidity. Eur. J. Soil Sci. 2001, 52, 151-165. [CrossRef]

43. Breś, W. Anthropopressure factors causing trees to die off in Urban landscape. Nauka Przyr. Technol. $2008,2,31$.

44. Pakuła, K. Frakcje ołowiu, chromu, cynku, miedzi i niklu w poziomach powierzchniowych gleb zlokalizowanych obok obwodnicy Siedlec. Inżynieria Ekol. 2011, 27, 153-159.

45. Dusza-Dobek, A. Geochemical studies of soils in some city parks of Warsaw. Biul. Państwowego Inst. Geol. 2012, 450, 35-46.

46. Bosiacki, M.; Kleiber, T.; Markiewicz, B. Continuous and Induced Phytoextraction-Plant-Based Methods of Remove Heavy Metals from Contaminated Soil. In Environmental Risk Assessment of Soil Contamination; Hernandez-Soriano, M.C., Ed.; InTech: Rijeka, Croatia, 2014; Volume 20, pp. 575-612. ISBN 978-953-51-1235-8.

47. Maliszewska-Kordybach, B.; Gałązka, R.; Klimkowicz-Pawlas, A.; Smreczak, B.; Łysiak, M. Czy gleby w Puławach są zanieczyszczone? Pol. J. Agron. 2012, 9, 7-16.

48. Kabata-Pendians, A.; Pendias, H. Trace Elements in Soils and Plants; CRC Press: Boca Raton, FL, USA, 2001.

49. Bosiacki, M.; Tyksiński, W. Dependence between the content of organic carbon and the content of cadmium and lead in horticultural substrates. Acta Agrophysica 2006, 7, 517-526. 